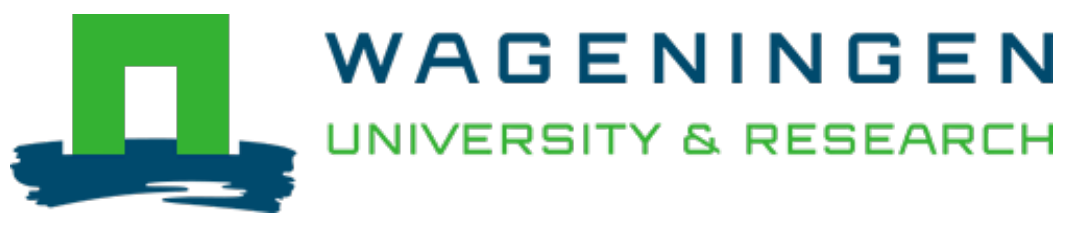

\author{
Processed weaning foods for tropical climates. \\ International Journal of Food Sciences and Nutrition \\ Nout, M.J.R. \\ https://doi.org/10.3109/09637489309027545
}

This publication is made publicly available in the institutional repository of Wageningen University and Research, under the terms of article $25 \mathrm{fa}$ of the Dutch Copyright Act, also known as the Amendment Taverne. This has been done with explicit consent by the author.

Article $25 \mathrm{fa}$ states that the author of a short scientific work funded either wholly or partially by Dutch public funds is entitled to make that work publicly available for no consideration following a reasonable period of time after the work was first published, provided that clear reference is made to the source of the first publication of the work.

This publication is distributed under The Association of Universities in the Netherlands (VSNU) 'Article $25 \mathrm{fa}$

implementation' project. In this project research outputs of researchers employed by Dutch Universities that comply with the legal requirements of Article $25 \mathrm{fa}$ of the Dutch Copyright Act are distributed online and free of cost or other barriers in institutional repositories. Research outputs are distributed six months after their first online publication in the original published version and with proper attribution to the source of the original publication.

You are permitted to download and use the publication for personal purposes. All rights remain with the author(s) and / or copyright owner(s) of this work. Any use of the publication or parts of it other than authorised under article $25 \mathrm{fa}$ of the Dutch Copyright act is prohibited. Wageningen University \& Research and the author(s) of this publication shall not be held responsible or liable for any damages resulting from your (re)use of this publication.

For questions regarding the public availability of this publication please contact openscience.library@wur.nl 


\title{
Processed weaning foods for tropical climates
}

\author{
M. J. R. Nout \\ Department of Food Science, Agricultural University, Bomenweg 2, 6703 HD Wageningen, \\ The Netherlands
}

Weaning foods must bridge the gap between breast-feeding and an 'adult' family diet. Infants aged 6-12 months are a major group of weaning food consumers. Their energy and protein requirements were used as a starting point to develop a strategy for the home or small-industrial scale manufacture of weaning foods. In addition such food must have an 'easy-to-swallow' consistency, and be microbiologically safe when consumed. On the other hand the level of anti-nutritional factors must be minimised. Ingredients must be locally available and acceptable. These would usually include a staple cereal or starchy tuber. The protein quantity and quality of the product can be optimised by adding legumes (beans, pulses) on the basis of their lysine content. Major problems to be solved include the bulkiness caused by starch gelatinisation and removal of the anti-nutritional factors which occur naturally in legumes. In addition, limited facilities for food preparation and storage allow contamination and rapid proliferation of micro-organisms which create risks of food-borne illness including diarrhoea. Several simple technologies are traditionally employed for the processing of cereals, tubers and legumes. These include roasting, germination and fermentation. Since these treatments have different effects on the quality characteristics of the final product, a combination of operations would therefore be a promising approach to optimise product quality at a minimum cost.

\section{Introduction}

- Protein energy malnutrition (PEM) and diarrhoea are major factors contributing to the high mortality of children under five years of age in tropical countries, estimated at more than 15 million per year. The infant ( $<1$ year) mortality rate in many tropical developing countries is $10-20$ times higher than in the industrialised regions (Grant, 1987).

The causes of PEM are complex. Inadequate total food intake or imbalanced food intake are important aspects. In addition, the resorption of nutrients is less efficient if children suffer from diarrhoea, which may be brought about by bacterial infections
(Cravioto et al., 1988; Molbak et al., 1989), viral infections (Singh et al., 1989), lactose intolerance and by food-related dysfunction of colon water management. Likewise, reduced nutrient absorption may result from accelerated intestinal passage caused by excessive amounts of gas from heterofermentative degradation of carbohydrates, for example.

\section{Product requirements}

Breast-feeding is considered best for infants, from nutritional and immunological points of view as well as for protection 
against Campylobacter-associated diarrhoea, for example (Megraud et al., 1990). However, time constraints and urbanisation (Uwaegbute and Nnanyelugo, 1987) are factors associated with early termination of breast-feeding. In addition, infants require complementary feeding from around the age of 4-6 months (Waterlow, 1981). A gradually increasing provision of complementary food causes a concomitant reduction in the child's dependence on breast milk; this reduction continues until the child can fulfil all his or her nutritional needs with an adult diet. Apart from nutritional concerns, the development of certain physical skills (the chewing and swallowing of relatively large quantities of solid food) determines the type of food that is appropriate at a particular age; the most problematic age is about 9-12 months, when an already considerable nutritional demand coincides with a still limited ability to masticate and swallow, and with a limited stomach capacity (Waterlow and Payne, 1975).

We have based the development of weaning foods on the nutritional requirements of children aged 6-12 months. The total food intake must supply $3500 \mathrm{~kJ}$ of energy and $14 \mathrm{~g}$ protein daily for a child weighing $7 \mathrm{~kg}$ (Hiel, 1984), as well as a variety of micronutrients (Renner, 1989). In addition, weaning foods must have an easy-to-swallow semi-liquid consistency $(1000-3000 \mathrm{cP})$, and be microbiologically safe when consumed. The level of antinutritional factors occurring naturally in the ingredients must be minimised by adequate processing.

Ingredients must be locally available and acceptable. These would usually include a staple cereal or starchy tuber, such as maize, sorghums, millets, rice, cassava or sweet potato. The protein quantity and quality of the starchy staple can be optimised by adding legumes (beans, pulses) (Oyeleke et $a l ., 1985)$ on the basis of their lysine content, which is limiting in most staples. For enrichment purposes soya, cowpea, groundnut, pigeon pea, bambara nut, kidney bean or mungbean are suitable.

Low-cost processing techniques must be employed, using simple equipment and energy-conserving operations.

\section{Challenges}

Major problems to be solved include:

(i) the bulkiness caused by starch gelatinisation. To supply daily $3000 \mathrm{~kJ}$ of energy in four feedings of $250 \mathrm{ml}$ each, weaning food porridge must have approxiately $20 \%$ dry matter content. At this concentration, a very stiff starch gel is obtained during cooking. Consequently, viscosity reduction is required.

(ii) reduction of the anti-nutritional factors which occur naturally in cereals and legumes. The major ANFs are protease inhibitors, phytic acid and oligosaccharides. Protease inhibitors could be subdivided into two groups, namely: (a) proteins including the Kunitz trypsin inhibitor which specifically binds to trypsin, and (b) non-specific protease inhibitors including tannins and lectins.

(iii) a microbial safety problem, caused by survival and growth of spoilage and pathogenic micro-organisms during the period between prepatation and feeding. Factors contributing to this effect are inadequate food and water hygiene (Lloyd-Evans et al., 1984; Molbak et al., 1989; Henry et al., 1990; Roberts, 1990), and the common practice of feeding left-overs stored at ambient temperature. Obviously, it is recommended that porridge should be boiled since it is the only way to inactivate viruses.

In this respect, the consumption of instant weaning formulas should not be encouraged as they invite the use of warm (not boiled) water for reconstitution. In any case, freshly prepared food will be safest. However, this is not always practicable.

There is a need for robust weaning foods which can be prepared in the morning for use throughout the day. In such foods, processing should impart anti-microbial activity to the product, thereby preventing the proliferation of post-preparation contaminations.

Several simple 'household technologies' are traditionally known for the processing of cereals, tubers and legumes. These include roasting, germination and fermentation 
(Alnwick et al., 1988). Since these treatments have different effects on the quality characteristics of the final product, a wellchosen combination of operations would therefore be a promising approach to optimise product quality at a minimum cost.

\section{Roasting}

Roasting or toasting can be best described as dry heating. It can be carried out on trays in an oven, on perforated carriers in a stream of hot air or in a slowly rotating drum with external heating. Due to its energy requirements, roasting is an expensive operation.

During roasting, several volatile substances including hexanal are removed by evaporation. The removal of such 'grassy' smelling substances, and the simultaneous onset of Maillard reactions give rise to an attractive flavour. Roasting has a slight viscosity-reducing effect on some cereals, but this is negligible in cereal-pulse mixtures (Nout, unpublished data). The content of tannins, phytic acid and oligosaccharides cannot be reduced by roasting.

However, roasting is carried out commonly in industrial practice to inactivate the Kunitz type of proteic trypsin inhibitors, haemagglutinins (Bressani and Elias, 1983) and lectins (Van der Poel, 1990). In soya beans, the enzyme urease is used as an indicator for adequate roasting. If this enzyme is inactivated, the Kunitz trypsin inhibitors are inactivated as well.

On the other hand, excessive roasting has a negative effect on the protein quality of the product since the Maillard reaction reduces the amount of available amino acids including lysine (Han et al., 1988).

For these reasons, the time-temperature combinations during roasting should be kept under control. As a rule of thumb, roasting should be continued until the product reaches an internal temperature of 90 $100^{\circ} \mathrm{C}$, after which it should be cooled rapidly by removing it from the toaster and spreading it out on a cooling table. Alternatively, it may be cooled using a fan.

From a microbiological point of view, roasting strongly reduces the number of vegetative cells of bacteria and fungi.
However, it does not protect the product from proliferation of post-processing contaminations.

An alternative to roasting is steaming. Preliminary results in our laboratory (Nout, unpublished data) resulted in adequate inactivation of Kunitz trypsin inhibitors and lectins without losses of available lysine, when presoaked beans were steamed for 10-20 minutes. An added advantage of this technique is that it is easier to standardise and requires less complicated equipment than roasting.

\section{Germination}

During germination, a large variety of plant endogenous enzymes are produced or activated, all having the biological function of mobilising the reserve polymers by degrading them to easily available water-soluble products. It is obvious, therefore, that humans resorb the nutrients in germinated seeds more easily than those in native seeds. Quite a number of scientific publications have appeared, dealing with the biotransformations during germination which are of nutritional relevance. Much information has been reviewed by Chavan and Kadam (1989a). Some of the desirable effects of germination include:

- reduction of viscosity, still enabling a semi-liquid consistency at $25 \%$ sorghum dry matter concentration, for example (Svanberg and Taal, 1985)

- decrease of tannin content in Vicia faba and red sorghum, for example, due to complexation with proteins (Chavan and Kadam, 1989a) (lectins were also inactivated in Phaseolus vulgaris (Nout, unpublished data))

- increased availability of amino acids including lysine, tryptophan and methionine (Chavan and Kadam, 1989a)

- partial degradation of phytic acid; however, this is not reflected in increased availability of minerals (Khetarpaul and Chauhan, 1989a), especially not in hightannin cereals (Svanberg and Lorri, 1988).

- gradual degradation of oligosaccharides: in Ph. vulgaris $77 \%$ of oligosaccharides 
were removed after three days germination; the product caused a reduction in breath hydrogen levels (Trugo et al., 1990).

However, germination does not appear to affect the Kunitz trypsin inhibitors and it does not improve the in vivo protein efficiency ratio (PER) (Malleshi and Desikachar, 1988; Ahrens et al., 1989; Chavan and Kadam, 1989a).

During germination, considerable respiration takes place which can cause dry matter losses of up to $25 \%$ (Chavan and Kadam, 1989a). It is therefore important to optimise the germination process and to use it only for those ingredients which will be nutritionally improved by it.

From a microbiological point of view, germination is a risky enterprise. There is an enormous increase in Enterobacteriaceae, fungi, Bacillus spp. etc., including potential pathogenic and toxinogenic species (Nout, 1980; Ogundiwin et al., 1991). In order to contain the proliferation of this microflora during later processing stages, the germinated seeds should be decontaminated by heating, or some other inhibitive principle must be applied.

\section{Fermentation}

In principle, several types of fermentation are suitable for processing cereals and legumes. Fungal fermentations, e.g. tempe fermentations by Rhizopus oligosporus and related organisms, have been welldocumented and are known to contribute to better digestibility and degradation of ANFs including phytic acid and oligosaccharides (Paredes Lopez and Harry, 1989; Liew and Buckle, 1990; Nout and Rombouts, 1990).

Within the African context, bacterial and yeast fermentations are better known and accepted. One of these is the fermentation of proteinous seeds by Bacillus subtilis, $B$. polymyxa, $B$. pumilus etc., giving aromatic products with a high degree of hydrolysis and a neutral $\mathrm{pH}$. Such fermentations might present interesting additional or alternative pre-treatment options, particularly for legumes.

Whereas yeast alcoholic fermentations are not desirable in weaning food, yeasts can play a role as a minority group in mixed microbial populations dominated by bacteria. Some yeasts possess carbohydrate degrading enzymes, e.g. $\alpha$-galactosidase, which are absent in certain lactic acid bacteria of plant origin. Also, yeasts supply vitamins, peptides and other micronutrients into the environment which support the growth of fastidious organisms, e.g. lactic acid bacteria.

Fermentation of cereals or roots crops alone or in mixtures with legumes can be carried out with Enterobacteriaceae of plant origin and lactic acid bacteria. The common characteristic of such fermentations is the production of organic acids resulting in a reduction of the $\mathrm{pH}$ and a typical sour taste. In the African continent, this type of fermentation is widely distributed and popular, especially in the rural communities.

Such lactic fermentation processes can be distinguished by the starter and reaction conditions employed as shown in Table 1 . The first two types of processes can be described as simple, low-technology, lowcost and semi-artisanal. On the other hand, controlled pure culture processes require adequate equipment and training. They are economically feasible at industrial scale production and at conditions of adequate efficiency. This type of process can offer specific advantages, e.g. the use of improved microbial strains, but from the food security point of view the inherent centralisation of production makes for a vulnerable situation.

\section{Effects of lactic fermentations}

Biotransformations. The impact of fermentation on the nutritional value of cereals has been reviewed by Chavan and Kadam (1989b). As far as we have been able to

Table 1. Fermentation starters and reaction conditions

\begin{tabular}{lll}
\hline Starter & Conditions & Character of process \\
\hline $\begin{array}{c}\text { None } \\
\begin{array}{c}\text { Stable natural } \\
\text { mixed culture }\end{array}\end{array}$ & $\begin{array}{l}\text { Non-sterile } \\
\text { Non-sterile }\end{array}$ & $\begin{array}{l}\text { Wild or spontaneous } \\
\text { Controlled mixed } \\
\text { culture }\end{array}$ \\
$\begin{array}{c}\text { Single or mixed } \\
\text { pure cultures }\end{array}$ & Sterile & $\begin{array}{c}\text { Controlled pure } \\
\text { culture }\end{array}$ \\
\hline
\end{tabular}


measure, lactic fermentations do not affect the Kunitz trypsin inhibitors. They do not cause a reduction of the viscosity in the boiled product; on the contrary, the acidity causes a viscosity increase in mixtures with soya or black gram (Phaseolus mungo), for example (Changala Reddy et al., 1989). From a nutritional point of view, the level of B vitamins increases (especially riboflavin) and there may be a slight increase of available lysine and methionine (Tomkins et al., 1990).

With reference to the ANFs, phytic acid (Khetarpaul and Chauhan, 1989b) and oligosaccharides (Zamora et al., 1989) are significantly reduced; also tannins are partly reduced (Khetarpaul and Chauhan, 1989b). As a result, the availability of minerals increases (Svanberg and Sandberg, 1989) as well as the digestibility of the proteins (Lorri and Svanberg, 1988). The PER of sorghum porridge increased from 2.06 to 2.34 during $24 \mathrm{~h}$ of fermentation with Lactobacillus plantarum (Ahrens et al., 1989). The RNV (relative nutritive value) of mungbean increased by $24 \%$ after fermentation with a mixture of lactic acid bacteria (Zamora et al., 1989). No information on the fate of lectins is available.

Microbial products. The formation of organic acids including lactic, acetic, butyric, propionic and isobutyric acids causes characteristic flavour. Probably more important, the combination of reduced $\mathrm{pH}$ and the presence of approximately $1-1 \frac{1}{2} \%(\mathrm{w} / \mathrm{w})$ lactic and acetic acid significantly inhibits the growth of Bacillaceae, Micrococcaceae and Enterobacteriaceae and consequently has a powerful stabilising effect on the microbial population in the product.

In addition, lactic acid bacteria produce small amounts of $\mathrm{H}_{2} \mathrm{O}_{2}$ and $\mathrm{CO}_{2}$ which both have some anti-microbial effect (Schaack and Marth, 1988). Recently, much interest has developed concerning the production and anti-microbial activity of bacteriocins (Spelhaug and Harlander, 1989), substances of proteinic nature which are inhibitive to similar organisms as the producer. Although there are limited application possibilities of bacteriocins in industrial food preservation, their importance should not be exaggerated because their stability is limited and they usually do not have a broad spectrum of anti-microbial activity.

Effect of live cells. It has been shown that certain fermented milk products, e.g. yoghurt and bifidus milk, have therapeutic effects in diarrhoeal disease (Boudraa et al., 1989). In these products, the presence of live cells of lactic acid bacteria is considered essential since they can survive the gastric barrier and produce enzymes, e.g. $\beta$ galactosidase, in the duodenum (Pochart et al., 1989). Also, live lactic acid bacteria may play a role in the exclusive colonisation of the gut and contribute to the colonisation resistance against intestinal pathogens. Lactococcus lactis increased the $\operatorname{IgA}$ production in mice and provided protection against Salmonella typhimurium (Perdigon et al., 1990a). Similar effects were observed with Lactobacillus casei and Lb. acidophilus (Goldin, 1989; Perdigon et al., 1990b).

\section{Microbial safety}

When we consider the safety of the product at the time of consumption, lactic fermentation significantly contributes to the microbial safety (Nout et al., 1989a; 1989b; Mensah et al., 1990), if the $\mathrm{pH}$ of the ready-to-eat product is $\leqslant 4.5$ and preferably $\leqslant 4.0$. Such $\mathrm{pH}$ values usually correspond to $1-1 \frac{1}{2} \%$ (w/w) lactic acid. Whether these conditions will be met depends on the adequacy of the fermentation process, the ingredients used and their buffering capacity, the dry matter content of the product and factors such as temperature and timing.

Like the other operations, fermentation also has possible disadvantages. The most important is that it is carried out in a high moisture product. This requires a more complex process compared with the production of a dry flour mixture. In addition, if a dry flour is the desired final product, the wet fermented material must be dehydrated. Both aspects (equipment and dehydration) increase the processing cost.

A second point is that extremely acidic products might not be tolerated by all individuals. In particular, sick people or those who are acidosic or suffer heartburn 


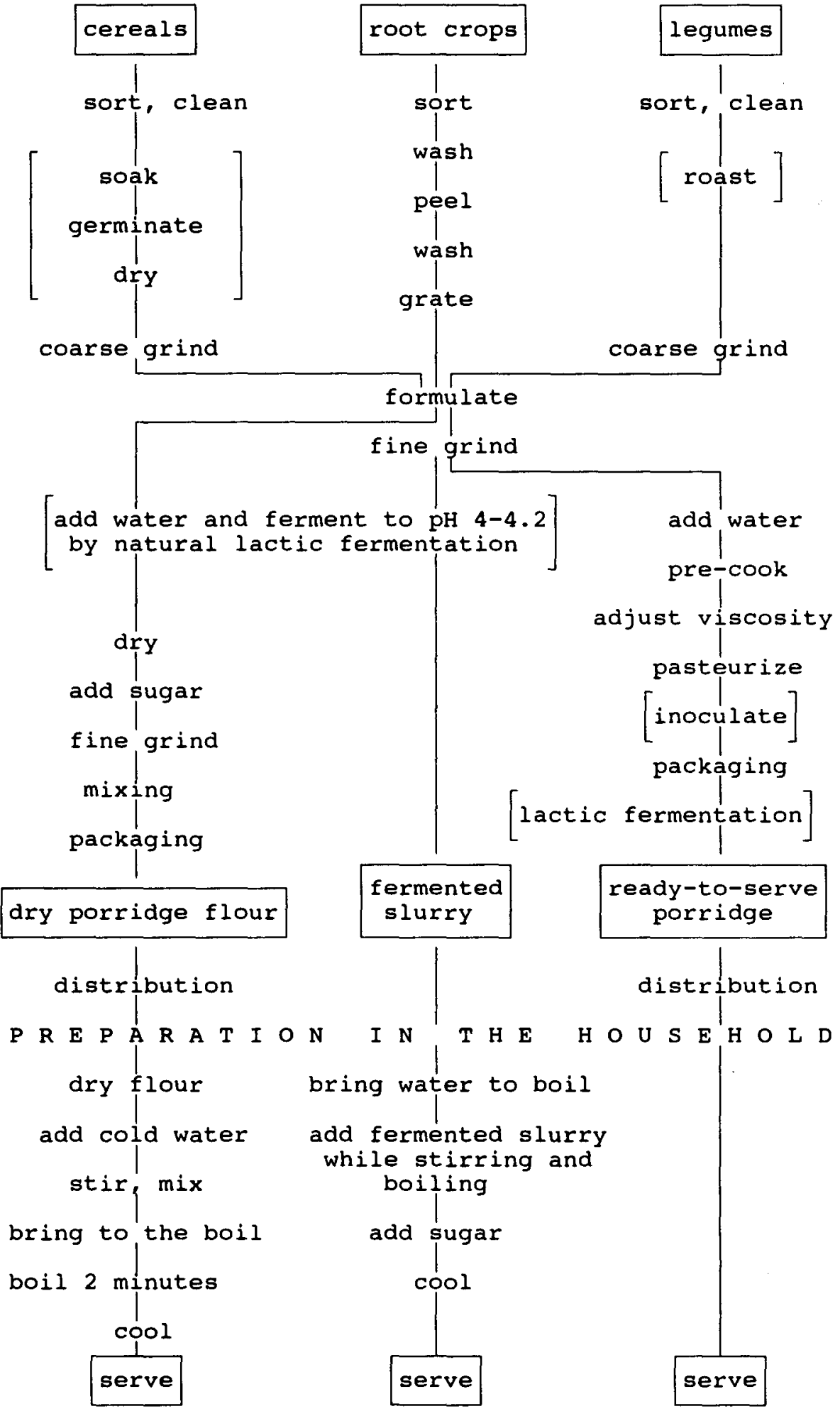

Figure 1. Technological options for weaning food manufacture 
should determine cautiously whether they can take the sour lactic-fermented products (Tomkins et al., 1990).

\section{Integration (at household or small-industrial scale)}

In the above sections it has been shown that specific benefits may be expected from roasting, germination and lactic fermentation. The optimum choice of technology and scale of production will depend on factors such as:

- raw materials available at the time, and their price - this will determine the combination of staples and legumes with maximum nutritive potential and consumer acceptance (Bressani and Elias, 1983)

- local cost of energy, building construction, road transport, wages and other indirect production costs (Harper and Tribelhorn, 1985)

- composition of the market, e.g. consumer density per $\mathrm{km}^{2}$, level of education, and extent of Government campaigning or institutional policy to popularise the consumption of the formulated weaning food

With reference to the process, several scenarios are outlined as follows (Figure 1):

(i) during raw material preparation:

- germination of cereals,

- roasting of legumes

(ii) during manufacturing of a formulated food:

- natural controlled lactic fermentation and drying to give a powder with long shelf-life. This type of product has the best properties for nationwide distribution and shelf-stability, but requires most work and fuel energy at the household level.

- natural controlled lactic fermentation and direct sale to the consumer who uses the product to prepare weaning porridge at home as soon as possible. This option is suitable only if no distribution is required, e.g. production and use within the household, or sale within an urban market. The case of Mawé in Cotonou is a good example of such situation. Mawé (Hounhouigan et al., 1992) is a traditional lactic fermented maize dough, sold at the market as an intermediate product to be prepared into a variety of dishes at household level.

- single or mixed pure culture fermentation in pre-cooked and (preferably) pre-packed product. This option is a bit more sophisticated and expensive, but offers in exchange:

- saving of time and fuel energy at the household level,

- product integrity by proper packaging,

- the possible beneficial effect of living lactic acid bacteria in the intestine.

At present, preliminary impact trials are being undertaken with the objective of testing the acceptability of combi-processed weaning foods and the feasibility of their manufacturing process.

\section{References}

Ahrens RA, Kibor A, Kigutha HN, Kipchillat P, Mbugua SK \& Smith FJ (1989): Improvement of the protein efficiency ratio (PER) of Kenyan weaning diets by fermentation. FASEB J. 3(4), A1263.

Alnwick D, Moses S \& Schmidt OG (eds) (1988): Improving young child feeding in eastern and southern Africa. Household level food technology. In Proceedings of a workshop held in Nairobi, Kenya, 12-16 October 1987. Publication IDRC-265e. Ottawa, Canada: International Development Research Centre.
Boudraa G, Touhami M, Pochart P, Soltana R, Mary JY \& Desjeux JF (1989): Effets comparés du yaourt et du lait sur la diarrhée persistante du nourrisson et de l'enfant: résultats préliminaires. In Les laits fermentés; actualité de la recherche; Congrès International, 14-16 Décembre 1989, Palais des Congrès, Paris, France, pp. 229-232. Paris: Coordination Scientifique/London: John Libbey.

Bressani R \& Elias LG (1983): Guidelines for the development of processed and packaged weaning foods. UNU Food Nutr. Bull. 5(3), 57-64. 
Changala Reddy G, Susheelamma NS \& Tharanathan RN (1989): Viscosity pattern of native and fermented black gram flour and starch dispersions. Starch/ Stärke 41(3), 84-88.

Chavan JK \& Kadam SS (1989a): Nutritional improvement of cereals by sprouting. CRC Crit. Rev. Food Sci. Nutr. 28(5), 401-437.

Chavan JK \& Kadam SS (1989b): Nutritional improvement of cereals by fermentation. CRC Crit. Rev. Food Sci. Nutr. 28(5), 349-400.

Cravioto A, Reyes RE, Ortega R, Fernandez G, Hernandez R \& Lopez D (1988): Prospective study of diarrhoeal disease in a cohort of rural Mexican children: incidence and isolated pathogens during the first two years of life. Epidemiol. Infect. 101, 123-134.

Goldin BR (1989): Lactic acid bacteria: implications for health. In Les laits fermentés; actualité de la recherche; Congrès International, 14-16 Décembre 1989, Palais des Congrès, Paris, France, pp. 95-104. Paris: Coordination Scientifique/London: John Libbey.

Grant JP (1987): The state of the world's children 1987. Oxford: Oxford University Press.

Han IK, Kim SW, Chae BJ, Ha JK, Park YJ \& Lee YS (1988): Bio-availability of amino acids in cereals and legumes. In Proceedings, Fifth Asian Congress of Nutrition, Osaka, Japan, 26-29 October 1987, eds. K Yasumoto, Y Itokawa, H Koishi \& Y Sanno, pp. 351-354. Tokyo: Center for Academic Publications.

Harper JM \& Tribelhorn RE (1985): Comparison of relative energy costs of village-prepared and centrally processed weaning foods. UNU Food Nutr. Bull. 7(4), 54-60.

Henry FJ, Patwary Y, Huttly SRA \& Aziz KMA (1990): Bacterial contamination of weaning foods and drinking water in rural Bangladesh. Epidemiol. Infect. 104, 79-85.

Hiel AMM (1984): Young children and supplementary feeding programmes: a field guide for the use of local foods and dried skim milk in Africa. Wageningen: The Netherlands Nutrition Foundation.

Hounhouigan DJ, Jansen JMM, Nout MJR, Nago MC \& Rombouts FM (1992): Production and quality of maize-based fermented dough in Benin urban area. In Proceedings of a Regional Workshop on Traditional African Foods - Quality and Nutrition, 25-29 November 1991, eds. A Westby and PJA Reilly, pp. 9-18. Stockholm: International Foundation for Science.

Khetarpaul N \& Chauhan BM (1989a) Effect of germination and pure culture fermentation on HCl-extractability of minerals of pearl millet (Pennisetum typhoideum). Int. J. Food Sci. Technol. 24(3), 327-331.

Khetarpaul N \& Chauhan BM (1989b): Effect of fermentation by pure cultures of yeasts and lactobacilli on phytic acid and polyphenol content of pearl millet. J. Food Sci. 54(3), 780-781.

Liew CCV \& Buckle KA (1990): Oligosaccharide levels in pigeonpea and pigeonpea tempe. ASEAN Food J. 5(2), 79-81.

Lloyd-Evans N, Pickering HA, Goh SGJ \& Rowland MGM (1984): Food and water hygiene and diarrhoea in young Gambian children: a limited case control study. Trans. R. Soc. Trop. Med. Hyg. 78, 209-211.

Lorri WSM \& Svanberg U (1988): Improved protein digestibility in cereal based weaning foods by lactic acid fermentation. Presented at the 3rd Africa Food and Nutrition Congress, Harare, Zimbabwe, 5-8 September 1988.

Malleshi NG \& Desikachar HSR (1988): Reducing the paste viscosity (dietary bulk) of roller dried weaning foods using malt flour or fungal amylase. J. Food Sci. Technol. India 25, 1-3.

Megraud F, Boudraa G, Bessaoud K, Bensid S, Dabis F, Soltana R \& Touhami M (1990): Incidence of Campylobacter infection in infants in western Algeria and the possible protective role of breast feeding. Epidemiol. Infect. 105, 73-78.

Mensah PPA, Tomkins AM, Drasar BS \& Harrison TJ (1990): Fermentation of cereals for reduction of contamination of weaning foods in Ghana. Lancet 336, 140-143.

Molbak K, Hojlyng N \& Jepsen S (1989): Bacterial contamination of stored water and stored food: a potential source of diarrhoeal disease in West Africa. Epidemiol. Infect. 102, 309-316.

Nout MJR (1980): Microbiological aspects of the traditional manufacture of Busaa, a Kenyan opaque maize beer. Chem. Mikrobiol. Technol. Lebensmittel 6, 137-142.

Nout MJR, Rombouts FM \& Havelaar A (1989a): Effect of accelerated natural lactic fermentation of infant food ingredients on some pathogenic microorganisms. Int. J. Food Microbiol. 8, 351-361.

Nout MJR, Rombouts FM \& Hautvast GJ (1989b): Accelerated natural lactic fermentation of infant food formulations. UNU Food Nutr. Bull. 11(1), 65-73.

Nout MJR \& Rombouts FM (1990): Recent developments in tempe research. J. Appl. Bacteriol. 69, $609-633$.

Ogundiwin JO, Ilori MO, Fessehatzion B, Babalola GO \& Olajuyigbe AO (1991): Effect of chemical treatments on the micro-organisms associated with malting of sorghum grains and sorghum malt. $J$. Appl. Bacteriol. 71, 139-143.

Oyeleke OA, Morton ID \& Bender AE (1985): The use of cowpeas (Vigna unguiculata) in improving a popular Nigerian weaning food. Br. J. Nutr. 54, 343-347.

Paredes Lopez O \& Harry GI (1989): Changes in selected chemical and antinutritional components during tempeh preparation using fresh and hardened common beans. J. Food Sci. 54(4), 968-970.

Perdigon G, Alvarez S, Nader de Macias ME, Roux ME \& Pesce de Ruiz Holgado A (1990a): The oral administration of lactic acid bacteria increases the mucosal intestinal immunity in response to enteropathogens. J. Food Prot. 53(5), 404-410.

Perdigon G, Nader de Macias ME, Alvarez S, Oliver G \& Pesce de Ruiz Holgado A (1990b): Prevention of gastrointestinal infection using immunobiological methods with milk fermented with Lactobacillus casei and Lactobacillus acidophilus. J. Dairy Res. 57(2), 255-264.

Pochart Ph, Dewit O, Desjeux JF \& Bourlioux P 
(1989): Viable starter culture, $\alpha$-galactosidase activity, and lactose in duodenum after yogurt ingestion in lactase-deficient humans. Am. J. Clin. Nutr. 49, 828-831.

Renner E (ed) (1989): Micronutrients in milk and milk-based food products. London: Elsevier Applied Science.

Roberts D (1990): Sources of infection: food. Lancet 336, 859-861.

Schaack MM \& Marth EH (1988): Interaction between lactic acid bacteria and some foodborne pathogens: $a$ review. Cultured Dairy Prod. J. 23(4), 14, 17-18, 20.

Singh PB, Sreenivasan MA \& Pavri KM (1989): Viruses in acute gastroenteritis in children in Pune, India. Epidemiol. Infect. 102, 345-353.

Spelhaug SR \& Harlander SK (1989): Inhibition of foodborne bacterial pathogens by bacteriocins from Lactococcus lactis and Pediococcus pentosaceous. J. Food Prot. 52(12), 856-862.

Svanberg U \& Lorri WSM (1988): Improved iron availability in weaning foods using germination and fermentation. Presented at the 3rd Africa Food and Nutrition Congress, Harare, Zimbabwe, 5-8 September 1988.

Svanberg U \& Sandberg A-S (1989): Improved iron availability in weaning foods using germination and fermentation. In Nutrient availability: chemical and biological aspects. Royal Society of Chemistry Special Publication No. 72, eds. DAT Southgate, IT Johnson and GR Fenwick, pp. 179-181. London: Royal Society of Chemistry.

Svanberg U \& Taal S (1985): Determination of viscosity - an important dietary bulk aspect of weaning foods. Food Laboratory Newsletter May 1985, 19-20.

Tomkins A, Alnwick D \& Watson F (1990): The potential role of fermentation and germination in improving young child feeding in eastern and southern Africa. Report of joint UNICEF/LSHTM project funded by the Overseas Development Administration (UK).

Trugo LC, Ramos LA, Trugo NMF \& Souza MCP (1990): Oligosaccharide composition and trypsin inhibitor activity of $P$. vulgaris and the effect of germination on the alpha-galactoside composition and fermentation in the human colon. Food Chem. 36(1), 53-61.

Uwaegbute AC \& Nnanyelugo DO (1987): Differences in the infant-feeding practices in urban and rural Nigeria. J. Nutr. Educ. 19(2), 83-89.

Van der Poel AFB (1990): Effects of processing on bean (Phaseolus vulgaris L.) protein quality. PhD Thesis, Wageningen Agricultural University.

Waterlow J (1981): Observations on the suckling's dilemma - a personal view. J. Hum. Nutr. 35, 85-98.

Waterlow J \& Payne PR (1975): The protein gap. Nature 258, 113-117.

Zamora AF, Gewan MG, Mangaban LM \& Olaivar E (1989): Nutritional quality of fermented mungbean (Vigna radiata Wilczek). In Trends in Food Biotechnology; Proceedings of the 7th World Congress of Food Science and Technology, Singapore, October 1987, eds. AH Ghee, NB Hen and LK Kong, pp. 249-252. Singapore Institute of Food Science and Technology. 